\title{
Enterprise Risk Management (ERM) and Firm's Performance: A Study of Listed Manufacturing Firms in Nigeria
}

\author{
Adegbola Olubukola Otekunrin ${ }^{1,4}$, Damilola Felix Eluyela ${ }^{1,4}$, Tony Ikechukwu Nwanji ${ }^{1,4}$, Sainey Faye ${ }^{2}$, Kerry E. \\ Howell $^{3} \&$ Jemima Tolu-Bolaji ${ }^{1}$ \\ ${ }^{1}$ Department of Accounting and Finance, Landmark University, Nigeria \\ ${ }^{2}$ Teesside University Business School, Teesside University, United Kingdom \\ ${ }^{3}$ School of Business, Law and Computing, Buckinghamshire New University, United Kingdom \\ ${ }^{4}$ Landmark University SDG 8 (Decent Work and Economic Growth Research Group), Nigeria \\ Correspondence: Damilola Felix Eluyela, Department of Accounting and Finance, Landmark University, Nigeria.
}

Received: February 24, 2020

Accepted: April 27, 2020

Online Published: January 3, 2021

doi:10.5430/rwe.v12n1p31

URL: https://doi.org/10.5430/rwe.v12n1p31

\begin{abstract}
Increased volatility in the business world has exposed the inadequacy of traditional approaches to risk management. This has led to an integrated approach to measuring and managing risks known as enterprise risk management (ERM). At the same time, past studies on ERM disclosures have examined it within the context of book-based approach, which has not given the right and accurate information. However, this paper examined the significance of enterprise risk management and listed manufacturing firms' financial performance in Nigeria using both the book-based approach and the market-based approach. Relevant ERM theories in relation to financial performance such as Agency Theory, Stakeholders Theory, and Enterprise Risk Management Theory were examined. A panel data analysis was employed on time series and cross-sectional data of thirty listed manufacturing firms in Nigeria from 2010 to 2018. The random effect of the Hausman test was found to be more appropriate and hence adopted in interpreting the results of the analysis. The results confirm the a priori expectations that profitability ratio, liquidity ratio, market-based ration to risk board committee, the board size, firm size, and directors' ownership all have varied impact on the firm's profitability with varied statistical significance levels.
\end{abstract}

Keywords: corporate governance, book-based ratio, enterprise risk management, financial performance, market-based ratio

JEL Classification Code: G32, G34, M41

\section{Introduction}

It is a fundamental objective of every company to make a profit and perform efficiently well in its operations. In any country, manufacturing firms have a part in developing the economy (Oladipo et al., 2019b). Financial performance is the empirical assessment of profitability and financial strength of any corporate concern (Umukoro et al., 2020). The financial statement review seeks to expose the value and importance of items published in income statements and statement of financial position that will assist management in the implementation of sound organizational and financial policies (Otekunrin et al., 2018a; 2018b). According to Angell and Brewer (2017), financial performance is calculated by asset usage, relative profitability, and the group's financial leverage. Angell and Brewer (2017) warn that with these three determinants, the main problem is that they rely on each other and that none of them can act independently to affect financial results. Achieving a stable financial performance, their adaptability to the business environment and risks associated with such organizations should be identified, assessed, and managed to not cause companies to be vulnerable to liquidation. In the market climate, these businesses' success is the main determinant of their existence and profitability.

Risk is an uncertainty that cannot be avoided but could be controlled. Financial services regularly face different aspects of risks in their operations. The financial performance of a company also depends on the risk taken but managed to a minimal level, and this is where the control of risk comes in to look at the steps taken to monitor the risk to an optimal level which would not affect the financial stability of the firm but rather increase it. Implementation of risk management strategy must be carried out by employees or hired personnel with a proper 
understanding of the effect of risk management and its results if adherently followed. Evolving in development with the changes in the business environment, the perception of risk management also changed and introduced a confined and re-structured level of responding to risk in risk management called, Enterprise Risk Management (ERM).

Enterprise Risk Management analyzes available data that identifies the performance or failures of uncertainties when choices are focused on the possible courses of action. Increasing the value of shareholders is the main objective of risk management (COSO, 2004; Pagach \& Warr, 2011; Liebenberg \& Hoyt, 2003). Risks are increasing, and risk management is becoming an integral part of almost every organization. Risk management policy not well implemented would have an adverse effect on the financial performance of financial services but could also lead to its liquidation. Enterprise Risk Management is seen as a top-down strategy to define, assess and respond to strategic, operational and financial threats to achieve certain goals: to achieve high-level objectives that fit with the purpose of the organization, to obtain effective and efficient use of resources, to ensure reporting reliability and comply with relevant laws and regulations.

In this study, net asset per share was used to measure financial performance because it measures both company market values and book values. There are two bases of assessing the financial performance of any firm. These are book-based and market-based approach (Vafeas, 1999; Eluyela et al., 2018a; 2018b). However, various studies such as (Ajibola, 2019; Nwanji et al., 2020; Olalere \& Wan Ahmad, 2016) used book-based approach (ROA, DER) which just focused on the financial statement and annual report of firms. The market based approach is more important because it gives more balanced and comprehensive information (Quon, Zeghal \& Maingot, 2012). Based on researchers' knowledge, the market-based approach has been scarce in previous studies. The market based approach was used in this study because of the short-comings in the book based approach, and this gives room for management of the firms to assess the happenings outside their company because the market changes based on stakeholder expectation. This gap serves as a motivation for this study.

Hence, the study seeks to ascertain a causal relationship between enterprise risk management on the financial performance of listed manufacturing firms. In achieving this, the rest of the study is structured in four sections. Next to the study's background is the second section, which contains the review of literature, empirical and theoretical evidences. Section three explains the research methods, and section four discusses data analysis and interpretation, while the last section contains conclusion, recommendation and areas of further research.

\section{Literature Review}

The literature is loaded with findings which demonstrate the effects of enterprise risk management on the financial performance of listed manufacturing firms

\subsection{Traditional Risk Management and Enterprise Risk Management}

Managing risk is becoming an imperative concern in the active and global environment of today's business world. In capital markets and an organisation's ability for decades to avoid, cut, balance or turn risks into opportunities, risk management has played a crucial role. However, it has developed from a traditional approach to a more modernized approach with time. Kraus and Lehner (2012) clarified the traceability of risk management to the 1940s and early 1950s. It began as a "silo-based" approach to enterprise risk management until the mid-1990s. Dickinson (2001) notes that the 'silo-based' approach is Traditional Risk Management (TRM), which is characterized by the management of individual risks in single units in a highly disaggregated system.

Therefore, the various types of risk are individually managed for this purpose; liquidity, credit, company, and operational risk. The disadvantages of this strategy are that, according to Eikenhout (2015), as the risk has to be segregated and personally managed, this leads to inefficiencies in risk management. He notes that traditional risk management focuses on finance and a case-by-case basis addresses risks, whereas enterprise risk management (ERM) addresses risks as a package and focuses not only on financial risks but also on non-financial risks. Saeidi, Sofian and AbdulRasid (2014) claim that a major paradigm shift in enterprise risk management was seen in the 1990s. Organizations indicated that they were using a more structured approach to risk management as an alternative to relying solely on silo-based risk assessment and resolution approaches.

\subsection{Agency Theory}

Agency theory extends the study of the firm to include division of ownership and control and managerial motivation. Management attitudes towards risk-taking and hedging have been shown to impact corporate risk management agency problems (Smith \& Stulz, 1985). This theory identifies a possible mismatch of interest between shareholders, management and debt holders due to earnings distribution asymmetries, resulting in the business taking too much risk or not engaging in a positive net value project. 
The use of derivatives is motivated by competing interests in the organizational relationship between managers and shareholders. Most senior managers have a highly undiversified financial status because they receive significant profits from their jobs (monetary and non-monetary). Risk aversion causes managers to deviate from acting purely in the best interest of shareholders by expending resources to hedge diversifiable risk, Managers and shareholders' time horizons can also vary because management compensation is related to short-term accounting steps. Via corporate risk management, these conflicts of interest may be mitigated if compensation systems properly relate managers' salaries to the firm's stock price. This means that a determinant of corporate hedging in a corporation could be the use of stock options contracts. Executive stock options will effectively minimize the risk aversion of a manager and lower the tendency to decrease idiosyncratic risk utilizing derivatives.

\subsection{Enterprise Risk Management and Firm Characteristics}

Some scholars have addressed the positive relationships between firm characteristics and the ERM software, but some other studies indicate unique factors that have no major effect on adopting ERM programs. Liebenberg and Hoyt (2003) argue that ownership features suggest no negligible link with the adoption of ERM programs. However, Pagach and Warr (2007) have found that it also does not affect the capital structure. Beasley, Pagach and Warr (2007); Liebenberg and Hoyt (2003) did not find proof of this opinion, even though some authors believe that an ERM software is appreciated more by companies with more growth opportunities.

Several studies hold that ERM is usually adopted by larger organizations (Pagach \& Warr, 2011, Beasley, Pagach \& Warr, 2007; Liebenberg \& Hoyt, 2003). The study of Hoyt and Liebenberg (2011) showed that companies with an integrated ERM program possess less financial risk. Saidu \& Gidado (2018) aimed to investigate the effect of managerial ownership on listed manufacturing firms' financial performance in Nigeria adopting regression and OLS analysis. They found out that managerial ownership has a negative impact on the performance of listed manufacturing companies.

Based on the literature reviewed above, the following hypothesis stated in the null form will be tested in the result and discussion section:

$\mathrm{H}_{01}$ : There is no significant relationship between enterprise risk management and profitability ratio of listed manufacturing firms in Nigeria.

$\mathrm{H}_{02}$ : There is no significant relationship between enterprise risk management and liquidity ratio of listed manufacturing firms in Nigeria.

$\mathrm{H}_{03}$ : Enterprise risk management has no significant influence on the market-based ratio of listed manufacturing firms in Nigeria.

\section{Data and Methodology}

This study adopted yearly observation rather than daily, monthly or quarterly observations (Adebayo et al., 2020; Oladipo et al., 2019a; 2019c). The source of the yearly data was generated through the Nigerian stock exchange (NSE) site. Secondary data is generally suitable and advantageous when trying to get any data about a company's financial position and performance (Lawal, Babajide, Nwanji \& Eluyela, 2018; Ozordi et al., 2019; 2020). The study adopted a quantitative research design approach (See Adetula et al., 2016; Akintimehin et al., 2019). This method enables data collection from reports on the financial statements from the listed manufacturing firms within the time frame of nine years (2010-2018) for the period under study.

This study is based on panel data methodological approach (Eluyela et al., 2019a; 2019b). The study's populace comprises all the 53 manufacturing firms listed on Nigeria stock exchange. This is made up of 28 firms listed on the consumer goods sector and 25 firms listed on the industrial goods sector. The sample size was selected based on the availability of complete data for the period under review (2010-2018). This study's sample size is 30 listed manufacturing firms comprising of 15 firms each for consumer and industrial goods sector.

The data analysis method is the panel data regression technique (Adegboyegun et al., 2020a; 2020b; Ademola et al., 2020b). Firstly, the descriptive statistics were presented in the result section. The descriptive statistics contain the measure of the central tendency of all variables (Ezenwoke et al., 2020; Inegbedion et al., 2020; Popoola, Asaleye \& Eluyela, 2018). This includes the mean, median, standard deviation, minimum and maximum values of all variables (Folashade et al., 2016). Following the result of the descriptive statistics, the correlation analysis was presented (Ademola et al., 2020a). The correlation analysis is used to confirm the presence of multicollinearity between variables. Based on the a priori expectations, there should be an absence of multicollinearity among variables. According to Okere et al (2019), multicollinearity is present when any variable's correlation values are higher than 0.8 . 
The Hausman test was used to confirm the model that fits the study. There are two types of models under the Hausman test (random and fixed effects model). Based on the result of the Hausman test, the panel data regression technique was presented. Under the panel regression technique, the variables' probability values were used to accept or reject the hypothesis stated in the the literature review section.

\subsection{Model Specification}

The regression model of Eluyela et al., (2020) provides a useful guide on the independent variables that affect enterprise risk. The model specification of this study is as follows:

$$
\begin{gathered}
y=f(x) \\
Y_{i t}=\beta_{0}+\beta_{1} X_{1}+\beta_{2} X_{2}+\beta_{3} X_{3}+\beta_{4} X_{4} \sum_{i t}
\end{gathered}
$$

Where;

$\mathrm{X}_{1}=$ Risk Management Committee

$\mathrm{X}_{2}=$ Company Size

$\mathrm{X}_{3}=$ Directors Ownership

$\mathrm{X} 4$ =Board Size

$\beta_{0}=$ Constant

$\beta_{1}=$ Slope of $\mathrm{X}_{1}$

$\beta_{2}=$ Slope of $\mathrm{X}_{2}$

$\beta_{3}=$ Slope of $\mathrm{X}_{3}$

$\beta_{4}=$ Slope of $\mathrm{X} 4$

$\sum_{i t}=$ Error term

Further explanation of the model specification for the study is;

$$
\begin{gathered}
R O A_{i t}=\beta_{0+} \beta_{1} R M C_{i t}+\beta_{2} C S_{i t}+\beta_{3} D O_{i t}+\beta_{4} B O_{i t}+\sum_{i t} \\
D E R_{i t}=\beta_{0+} \beta_{1} R M C_{i t}+\beta_{2} C S_{i t}+\beta_{3} D O_{i t+} \beta_{4} B O_{i t}+\sum_{i t} \\
N P S_{i t}=\beta_{0+} \beta_{1} R M C_{i t+} \beta_{2} C S_{i t+} \beta_{3} D O_{i t+} \beta_{4} B O_{i t+} \sum_{i t}
\end{gathered}
$$

\subsection{Variables Measurement}

\begin{tabular}{|c|c|c|}
\hline Variable Type & Name of Variable & Measurement \\
\hline \multirow[t]{3}{*}{ Dependent Variables } & Return on Asset (ROA) & Profit after taxation divided by total assets \\
\hline & Debt to equity ratio (DER) & Total debt divided by total equity \\
\hline & Net Assets per Share & $\begin{array}{l}\text { Net asset divided by the number of ordinary shares in } \\
\text { issue }\end{array}$ \\
\hline \multirow[t]{2}{*}{ Independent } & Risk Board Committee & Presence of risk board in the organization \\
\hline & Firm Size & Log of total assets \\
\hline \multirow[t]{2}{*}{ Control } & Director Ownership & $\%$ of director ownership divided by total shares \\
\hline & Board Size & Number of the board of directors \\
\hline
\end{tabular}

The measured variables used in this study are an indicator of Enterprise risk management and financial performance of listed financial services. The independent variable is enterprise risk management, while the dependent variable is financial performance. Table 1 shows the various variables used in the study and their measurement.

Table 1. Measurement of variables

Source: Authors Compilation (2020) 


\section{Result and Discussion}

To analyze the profitability pattern of these selected quoted manufacturing firms, this study used econometric analytical tools to analyze the 30 selected manufacturing firms for this study. The analysis comprises of 270 observations for the 2010-2018 period. The variables reviewed are: Return on Assets, Debt Equity, Net asset Per Share, Director Ownership, Company Size, Risk Management Committee and Board Size as variables.

Table 2. Descriptive statistics

\begin{tabular}{llllllll}
\hline & ROA & NPS & DER & DOWN & FSIZE & RBC & BSIZE \\
\hline Mean & 0.480259 & 3.006691 & 3.713465 & 2.674872 & 7.513977 & 0.896552 & 11.58148 \\
\hline Median & 0.028635 & 0.835300 & 1.276800 & 2.097150 & 7.245600 & 1.000000 & 11.00000 \\
\hline Maximum & 16.28340 & 477.8175 & 191.2000 & 9.736200 & 10.03910 & 1.000000 & 26.00000 \\
\hline Minimum & -0.061700 & 0.000000 & 0.000000 & 0.000000 & 0.000000 & 0.000000 & 0.000000 \\
\hline Std. Dev. & 1.877441 & 29.09591 & 12.01513 & 2.054890 & 1.215982 & 0.305129 & 3.911525 \\
\hline Skewness & 5.408523 & 16.18856 & 14.25978 & 0.971906 & -1.892171 & -2.604237 & 0.399051 \\
\hline Kurtosis & 36.46161 & 264.6184 & 222.1783 & 3.820681 & 15.68871 & 7.782051 & 4.324578 \\
\hline Jarque-Bera & 13912.74 & 781790.1 & 547555.2 & 49.71312 & 1965.096 & 543.7089 & 26.90408 \\
\hline Probability & 0.000000 & 0.000000 & 0.000000 & 0.000000 & 0.000000 & 0.000000 & 0.000001 \\
\hline & & & & & & \\
\hline Sum & 129.6700 & 811.8066 & 998.9220 & 716.8657 & 2021.260 & 234.0000 & 3127.000 \\
\hline Sum Sq. Dev. & 948.1667 & 227727.9 & 38689.38 & 1127.427 & 396.2683 & 24.20690 & 4115.707 \\
\hline & & & & & & \\
\hline Observations & 270 & 270 & 269 & 268 & 269 & 261 & 270 \\
\hline Source: Aun's & & & & & & &
\end{tabular}

Source: Author's computation using E-VIEWS

Table 2 shows a detailed summary of the descriptive statistics of all variables. A careful examination of the result shows that the mean value of the firms' return on assets is $48 \%$, which indicates that the firms have a good profitability performance. The mean value of the net asset per share is $300 \%$, and the mean value of the debt to equity ratio is $371 \%$. The mean values of the director's ownership, firm size, risk board committee and board size are $267 \%, 751 \%, 90 \%$ and $1158 \%$ respectively. This indicates that the firms' size is very large and so there is a high amount of the director's ownership and the risk board committee.

The result also shows the maximum values of the dependent variables ROA, DER, and NPS, which are very high due to the large size of the firms but the minimum values are too low compared with the maximum values. This is same with the independent variables; DOWN, FSIZE, RBC, and BSIZE which have very high maximum values but the minimum values are too low.

Table 3. Correlation Analysis

\begin{tabular}{lrrlllll}
\hline & \multicolumn{1}{l}{ ROA } & NPS & DER & DOWN & FSIZE & RBC & BSIZE \\
\hline ROA & 1.000000 & & & & & \\
\hline NPS & -0.021395 & 1.000000 & & & & \\
\hline DER & 0.038917 & -0.012532 & 1.000000 & & & \\
\hline DOWN & -0.014749 & 0.015096 & 0.049828 & 1.000000 & & \\
\hline FSIZE & 0.045746 & 0.020694 & 0.089000 & 0.238454 & 1.000000 & \\
\hline
\end{tabular}




\begin{tabular}{llllllll}
\hline RBC & 0.081265 & 0.024880 & 0.088457 & 0.308489 & 0.325689 & 1.000000 & \\
\hline BSIZE & 0.025939 & 0.084750 & 0.033172 & 0.053135 & 0.025973 & 0.067802 & 1.000000 \\
\hline
\end{tabular}

Source: Author's computation using E-VIEWS

Table 3 shows that there is a negative link between ROA and DOWN which implies that for every unit change in ROA, there will be a $1.5 \%$ decrease in the director's ownership of the firms although there is also a good relationship in the table between ROA and FSIZE, RBC and BSIZE, which implies that for every unit change in ROA there will be a $4.6 \%, 8.1 \%$ and $2.6 \%$ increase in the firms' size, risk board committee and board size respectively.

The second dependent variable, NPS, shows a positive relationship with DOWN, FSIZE, RBC and BSIZE, and this indicates a change of unit in NPS will result in $1.5 \% .2 .1 \%, 2.5 \%$ and $8.5 \%$ increase in the director's ownership, firm size, and risk board committee and board size respectively. The third dependent variable DER is also positively correlated with the independent variables DOWN, FSIZE, RBC and BSIZE. For every unit change in DER, there will be a 5\%,9\%, 8.8\% and 3.3\% increase in the director's ownership, firm size, risk board committee and board size respectively.

The results indicate that director's ownership has a negative impact on the profitability execution of the firms while the firm size, risk board committee and board size have a positive effect on the Profitability performance of corporations and general financial performance. The correlation matrix is also used to detect multicollinearity between the variables. Multicollinearity exists when the coefficient of pair correlation between regressions is more than 0.8. Therefore, since the correlation table above does not have such traits, then it can be concluded that there is an absence of multicollinearity.

\subsection{Hausman Test}

In this section, the hausman test was used to determine whether the fixed or random effect model is appropriate for each model specification. Thereafter, a regression analysis was presented to show the coefficient of correlation, the coefficient of determination and the probability value of each variable.

The rule for the Hausman test states that if the $\mathrm{p}$-value is statistically significant $(\mathrm{p}<0.05)$, the fixed effect estimator should be applied and if the p-value is not statistically significant ( $>0.05$ ), the random effect estimator should be applied. Table 4 presents the Hausman test for all the three dependent variables.

Table 4. Hausman test

\begin{tabular}{llll}
\hline $\begin{array}{l}\text { Dependent } \\
\text { Variables }\end{array}$ & Chi-Sq. Statistic & Prob. Values & Decision \\
\hline ROA & 1.208651 & 0.8767 & Random effect \\
\hline DER & 1.334260 & 0.8555 & Random effect \\
\hline NPS & 16.497422 & $0.0024^{*}$ & Fixed effect \\
\hline
\end{tabular}

* means that variable is statistically significant at $5 \%$ probability value.

Source: Author's computation using E-VIEWS

The probability value for ROA is 0.8767 , which is greater than $5 \%$ level of significance. Therefore, the random effect regression analysis model will be estimated in Table 5. For DER, the probability value is 0.8555 , which is higher than 5\% level of significance. The random effect regression analysis model will also be estimated in Table 6 . However, for NPS, the probability value is 0.0024 , which is lower than $5 \%$ level of significance. Hence, the fixed effect regression analysis model will be presented in Table 7. 
Table 5. Random effect regression analysis

\section{Dependent Variable: ROA}

Sample: 20102018

Periods included: 9

Cross-sections included: 29

Total panel (unbalanced) observations: 258

\begin{tabular}{lllll}
\hline Variable & Coefficient & Std. Error & t-Statistic & Prob. \\
\hline C & 1.145910 & 0.914103 & 1.253589 & 0.2113 \\
\hline RBC & 0.240774 & 0.504204 & 0.477532 & 0.0334 \\
\hline FSIZE & -0.020652 & 0.117117 & -0.176340 & 0.0002 \\
\hline DOWN & -0.083741 & 0.065205 & -1.284275 & 0.0004 \\
\hline BSIZE & -0.040895 & 0.058581 & -0.698095 & 0.4858 \\
\hline R-squared & 0.503798 & Mean dependent var & 0.497576 \\
\hline Adjusted R-squared & 0.433227 & S.D. dependent var & 1.918866 \\
\hline S.E. of regression & 1.444605 & Akaike info criterion & 3.692504 \\
\hline Sum squared resid & 469.5487 & Schwarz criterion & 4.146952 \\
\hline Log-likelihood & -443.3330 & Hannan-Quinn criter. & 3.875239 \\
\hline F-statistic & 7.138888 & Durbin-Watson stat & 1.988488 \\
\hline Prob(F-statistic) & 0.000000 & &
\end{tabular}

Source: Author's computation using E-VIEWS

Table 5 shows the panel regression of the dependent variable (ROA) and the independent variables (RBC, FSIZE, DOWN and BSIZE). The probability value of the F-statistics, which is 0.0000 is highly statistically significant at $5 \%$ level which explains that the model is significant. The relationship between risk board committee (RBC) and the firms' profitability is positive and significant with a correlation coefficient of 0.240774 and probability value of 0.0334 . This means that a unit increase in risk board committee will bring about a $24 \%$ increase in the sampled manufacturing listed firms' profitability ratio.

Table 6. Random Effect Regression Analysis

\section{Dependent Variable: DER}

Sample: 20102018

Periods included: 9

Cross-sections included: 29

Total panel (unbalanced) observations: 257

\begin{tabular}{lllll}
\hline Variable & Coefficient & Std. Error & t-Statistic & Prob. \\
\hline C & 3.358992 & 7.313319 & 0.459298 & 0.6465 \\
\hline RBC & 0.112472 & 4.032213 & 0.027893 & 0.0178 \\
\hline FSIZE & -0.083978 & 0.936531 & -0.089669 & 0.0286 \\
\hline DOWN & 0.073880 & 0.522293 & 0.141454 & 0.0276 \\
\hline BSIZE & 0.069971 & 0.468472 & 0.149359 & 0.8814 \\
\hline R-squared & 0.225183 & \multicolumn{2}{c}{ Mean dependent var } & 3.851340 \\
\hline
\end{tabular}




\begin{tabular}{llll}
\hline Adjusted R-squared & 0.114495 & S.D. dependent var & 12.27586 \\
\hline S.E. of regression & 11.55174 & Akaike info criterion & 7.850929 \\
\hline Sum squared resid & 29891.19 & Schwarz criterion & 8.306647 \\
\hline Log-likelihood & -975.8444 & Hannan-Quinn criter. & 8.034197 \\
\hline F-statistic & 2.034392 & Durbin-Watson stat & 2.283102 \\
\hline Prob(F-statistic) & 0.001555 & & \\
\hline
\end{tabular}

Source: Author's computation using E-VIEWS

Table 6 shows the panel regression of the dependent variable (DER) and the independent variables (RBC, FSIZE, DOWN and BSIZE). The probability value of the F-statistics, which is 0.001555 is statistically significant at $5 \%$ level, which explains that the model is significant.

The relationship between the firm size (FSIZE) and the firms' liquidity ratio is negative and statistically significant with a correlation coefficient of -0.083978 and probability value of 0.0286 . This means that a unit rise in firm size will lead to an $8.4 \%$ decrease in the firms' liquidity ratio. The relationship between RBC and DOWN and the firms' liquidity ratio are positive and statistically significant with correlation coefficients $0.112472,0.073880$ and probability values $0.0178,0.0276$, respectively. This means that each unit rises in RBC and DOWN, there will be $11.2 \%$ and $7.4 \%$ increase in the sampled firms' liquidity ratio.

The relationship between the board size (BSIZE) and DER specifies a positive but insignificant connection between the board size and the liquidity ratio of the firms with a correlation coefficient 0.069971 of and probability value of 0.8814 , which implies that a unit rise in BSIZE will lead to $7 \%$ increase in the liquidity ratio of the sampled firms.

Table 7. Fixed effect regression analysis

\begin{tabular}{|c|c|c|c|c|}
\hline Dependent Variable & & & & \\
\hline Sample: 20102018 & & & & \\
\hline Periods included: 9 & & & & \\
\hline Cross-sections includ & & & & \\
\hline Total panel (unbalan & ervations: 258 & & & \\
\hline Variable & Coefficient & Std. Error & t-Statistic & Prob. \\
\hline RBC & 3.994207 & 10.29406 & 0.388011 & 0.0084 \\
\hline FSIZE & 4.412003 & 2.391118 & 1.845163 & 0.0663 \\
\hline DOWN & 0.493946 & 1.331246 & 0.371040 & 0.0110 \\
\hline BSIZE & -3.407799 & 1.196007 & -2.849313 & 0.0048 \\
\hline $\mathrm{C}$ & 4.984670 & 18.66274 & 0.267092 & 0.0096 \\
\hline R-squared & 0.140285 & Mean depe & & 3.110969 \\
\hline Adjusted R-squared & 0.018014 & S.D. depen & & 29.76299 \\
\hline S.E. of regression & 29.49369 & Akaike inf & ion & 9.725185 \\
\hline Sum squared resid & 195722.6 & Schwarz cr & & 10.17963 \\
\hline Log-likelihood & -1221.549 & Hannan-Qu & iter. & 9.907921 \\
\hline F-statistic & 1.147329 & Durbin-Wa & & 1.307742 \\
\hline Prob(F-statistic) & 0.278027 & & & \\
\hline
\end{tabular}

Source: Author's computation using E-VIEWS 
Table 7 shows the panel regression of the dependent variable (NPS) and the independent variables (RBC, FSIZE, DOWN and BSIZE). The probability value of the F-statistics, which is 0.278027 is not statistically significant, which explains that the model is not significant.

The firms' board size (BSIZE) shows a negative but significant effect on the market ratio (proxy to debt-equity ratio) with a correlation coefficient of -3.407799 and probability value of 0.0048 . This means that a unit rise in board size will bring about a $3.4 \%$ decrease in the firms' market ratio. The firm size (FSIZE) has a positive but insignificant effect on the firms' market ratio with correlation coefficient 4.412003 of and probability value of 0.0663 . This implies that a unit rise in the firm size will bring about a $441 \%$ increase in the market ratio.

The risk board committee (RBC) and director's ownership (DOWN) indicate a positive and significant effect on the market ratio with correlation coefficients of $3.994207,0.493946$ and probability values $0.0084,0.0110$ respectively. This implies that a unit increase in RBC and DOWN will lead to $400 \%$ and $49 \%$ increase in the firms' market ratio.

\subsection{Hypothesis Testing}

Hypothesis one states that there is no significant relationship between enterprise risk management and profitability ratio of listed manufacturing firms in Nigeria. Table 5, under the the risk board committee (RBC), the coefficient of correlation is 0.24 , and the probability is 0.03 , which is lower than the 0.05 level of significance. Therefore, we will reject the null hypothesis and accept alternate. This implies a significant relationship between enterprise risk management and the profitability ratio of listed manufacturing firms in Nigeria.

Hypothesis two states that there is no significant relationship between enterprise risk management and liquidity ratio of listed financial services firms in Nigeria. Table 6, under the risk board committee (RBC), correlates with a correlation coefficient of 0.11 , and the probability is 0.01 , which is lower than the 0.05 level of significance. Therefore, we will reject the null hypothesis and accept alternate. This implies a significant relationship between enterprise risk management and the liquidity ratio of listed manufacturing firms in Nigeria.

Hypothesis three states that enterprise risk management has no significant influence on the market-based ratio of listed manufacturing firms in Nigeria. Table 7, the risk board committee (RBC), the coefficient of correlation is 3.99, and the probability is 0.008 , which is lower than the 0.05 level of significance. Therefore, we will reject the null hypothesis and accept alternate. This implies that enterprise risk management has a significant influence on the market-based ratio of listed manufacturing firms in Nigeria. This is in line with the work of the findings (Olalere \& Omar, 2016; Olusegun, 2019).

\section{Conclusion and Recommendations}

This research work helped determine whether there is an important connection between the management of enterprise risk and the financial performance of the listed manufacturing firms in Nigeria. This study concluded that enterprise risk management has a significant impact on listed manufacturing firms' financial performance in Nigeria. This study adds to the limited empirical evidence in the area of corporate risk and financial performance management. To illustrate board features and their impact on results, the analysis provided a complementary theoretical approach to agency theory, stakeholder theory and enterprise risk management theory.

The study recommends the following: organizations should look into the market-based area of the economy and not just making decisions based on the information written down which might go obsolete over time and they might end up making decisions on things are not relevant currently so they should also consider the market based whereby the opinion of people or choice of the people which are also the consumers could be considered in terms of making a decision. Also, the activities of the risk board committee should be monitored from time to time to ensure that the decisions of the risk board and the activities of it members of aligns with the vision of the company, as well as that these decisions and activities help to improve the financial results of the company. Furthermore, the board of directors should attempt to carry out a frequent and proper check on the organization or company's risk to ensure that the pit is adequately handled and on the different variables as it has a substantial positive or negative effect on their financial results.

\subsection{Suggestions for Further Studies}

In this study, enterprise risk management was limited to only four variables that were used to test for performance. Other characteristics that can be used to test for firms' performance, such as internal audit, credit risk, leverage, and firm's value, can be considered for further research on board characteristics and enterprise risk management. The measure of financial performance was also limited to three variables (return on asset, debt-equity, and net assets per 
share). However, more variables such as return on capital employed and return on asset can be used to measure performance. Further studies can consider using Tobin Q as a measure of market-based performance approach.

For the generality of findings, the sample size of the study can also be increased. Other industry sectors were not included in this study, because it looked to focus only on manufacturing firms listed on the Nigerian Stock Exchange. However, other sectors such as conglomerate, agro-allied, financial services and other sectors available on the Nigerian Stock Exchange can be employed for further studies.

\section{References}

Adebayo, R. F., Eluyela, D. F., Victor-Adisa, A., Olayanju, A., Popoola, O., Maimako, R., ... Dahunsi, O. (2020). Electricity supply and business performance in a Nigerian private university. International Journal of Energy Economics and Policy, 10(3), 497-503. https://doi.org/10.32479/ijeep.8555

Adegboyegun, A. E., Alade, M. E., Ben-Caleb, E., Ademola, A. O., Eluyela, D. F., \& Oladipo, O. A. (2020). Integrated reporting and corporate performance in Nigeria: evidence from the banking industry. Cogent Business and Management, 7(1). https://doi.org/10.1080/23311975.2020.1736866

Adegboyegun, A. E., Ben-Caleb, E., Ademola, A. O., Madugba, J. U., \& Eluyela, D. F. (2020). Fair value accounting and corporate reporting in Nigeria: a logistics regression approach. International Journal of Financial Research, 11(2), 301-310. https://doi.org/10.5430/ijfr.v11n2p301

Ademola, A. O., Ben-Caleb, E., Adegboyegun, A. E., Eluyela, D. F., Falaye, A. J., \& Ajayi, A. S. (2020b). Rotating and savings credit association (ROSCAs): A veritable tool for enhancing the performance of micro and small enterprises in Nigeria. International Asian Economic and Financial Review, 10(2), 189-199. https://doi.org/10.18488/journal.aefr.2020.102.189.199

Ademola, A. O., Ben-Caleb, E., Madugba, J. U., Adegboyegun, A. E., \& Eluyela, D. F. (2020a). International public sector accounting standards (IPSAS) adoption and implementation in Nigerian public sector. International Journal of Financial Research, 11(1), 434-446. https://doi.org/10.5430/ijfr.v11n1p434

Adetula, D. T., Eluyela, D. F., Akomolafe, A., Ilogho, S. O., \& Adubi, A. (2016). Cost management and performance of manufacturing companies: A study of listed firms in Nigeria. A paper presented at 28th International Business Information Management Association (IBIMA), November 9-10, Seville, Spain.

Ajibola, J. O. (2019). Enterprise risk management and bank performance. Academic Journal of Current Research, 6(3), 1-20.

Akintimehin, O. O., Eniola, A. A., Alabi, O. J., Eluyela, D. F., Okere, W., \& Ozordi, E. (2019). Social capital and its effect on business performance in the Nigeria informal sector. Heliyon, 5. https://doi.org/10.1016/j.heliyon.2019.e02024

Angell, R. J., \& Brewer, B. L. (2017). Improving the coverage of the DuPont approach of financial analysis in finance courses through the use of the net leverage multiplier. Journal of Economics and Finance Education, 2(2), 1199-1207.

Beasley, M. S., Pagach, D., \& Warr, R. (2007). Information conveyed in hiring announcements of senior executives overseeing enterprise-wide risk management processes. Journal of Accounting, Auditing and Finance, 24(6), 521-531.

COSO. (2004). Enterprise risk management - Integrated framework. New York, NY: Committee of Sponsoring Organizations of the Tredway Commission.

Dickinson, G. (2001). Enterprise risk management: Its origin and conceptual foundation. The Geneva, 26(3), 360-366.

Eikenhout, L. (2015). Risk management and performance in insurance companies. Master Thesis.

Eluyela, D. F., Adetula, D. T., Obasaju, O. B., Ozordi, E., Akintimehin, O., \& Popoola, O. (2019a). Foreign directors, indigenous directors and dividend payout structure in Nigerian deposit money banks. Banks and Bank System, 14(2), 1-14. https://doi.org/10.21511/bbs.14(2).2019.16

Eluyela, D. F., Akintimehin, O. O., Okere, W., Ozordi, E., Osuma, G. O., Ilogho, S. O., \& Oladipo, O. A. (2018a). Datasets for board meeting frequency and financial performance of Nigerian deposit money banks. Data in Brief. https://doi.org/10.1016/j.dib.2018.06.044 
Eluyela, D. F., Akintimehin, O. O., Ozordi, E., Oladipo, O. A., Ilogho, S. O., \& Okere, W. (2018b). Board meeting frequency and firm performance: examining the nexus in Nigerian deposit money banks. Heliyon, 4, 850. https://doi.org/10.1016/j.heliyon.2018

Eluyela, D. F., Bassey, I., Oladipo, A. O., Adegboyegun, A. E., Ademola, A., \& Madugba, J. (2020). Impact of capital flight on tax revenue in Nigeria: a co-integration approach. Research in World Economy, 11(5), 141-151. https://doi.org/10.5430/rwe.v11n5p141

Eluyela, D. F., Olajide, D., Tolase, O. A., Okere, W., Ogabi, M., \& Kafidipe, A. (2019b). Impact of gender dichotomy on dividend payout policy in listed Nigerian financial services firm. Cogent Business and Management, 6, 1-10. https://doi.org/10.1080/23311975.2019.1687270

Ezenwoke, O. A., Efobi, U. R., Asaleye, A. J., \& Felix, D. E. (2020). The determinants of undergraduate accounting students' early participation in professional examinations. Cogent Education, 8(1), 1815962. https://doi.org/10.1080/2331186X.2020.1818411

Folashade, O., Ilogho, S. O., Eluyela, D. F., Adewale, A. J., \& Ibanga, B. I. (2016). International financial reporting standards education and its inclusion in the Nigerian curriculum. Proceedings of the 28th International Business Information Management Association Conference - Vision 2020: Innovation Management, Development Sustainability, and Competitive Economic Growth, 4509-4516.

Hoyt, R. E., \& Lienberg, A. P. (2011). The value of enterprise risk management. Journal of Risk and Insurance, 78(4), 795-822.

Inegbedion, H. E., Adeyemi, S. O., Akintimehin, O., \& Eluyela, D. (2020). Teachers' time utilisation and students' enrolment in school certificate examination: implication for school leadership. Heliyon, 6(9), e04892, https://doi.org/10.1016/j.heliyon.2020.e04892

Kraus, V., \& Lehner, O. M. (2012). The nexus of enterprise risk management and value Creation: A systematic Literature Review. ACRN Journal of Finance and Risk Perspectives, 1(1), 91-163.

Lawal, A. I., Babajide, A. A., Nwanji, T. I., \& Eluyela, D. (2018). Are oil prices mean reverting? Evidence from unit root tests with sharp and smooth breaks. International Journal of Energy Economics and Policy, 8(6), 292-298. https://doi.org/10.32479/ijeep.6980

Liebenberg, A. P., \& Hoyt, R. E. (2003). The determinants of enterprise risk management: evidence from the appointment of chief risk officers. Risk Management and Insurance Review, 6(1), 37-52.

Nwanji, T. I., Howell, K. E., Faye, S., Otekunrin, A. O., Eluyela, D. F., Lawal, A. I., \& Eze, S. C. (2020). Impact of foreign direct investment on the financial performance of listed deposit banks in Nigeria. International Journal of Financial Research, 11(2), 323-347. https://doi.org/10.5430/ijfr.v11n2p323

Okere, W., Eluyela, D. F., Lawal, A. I., Ibidunni, O., Eseyin, O., Popoola, O., \& Awe, T. (2019). Foreign expatriates on board and financial performance: a study of listed deposit money banks in Nigeria. The Journal of Social Science Research, 5(2), 418-423. https://doi.org/10.32861/jssr.52.418.423

Oladipo, O. A., Fakile, A. S., Ajayi, S. A., \& Eluyela, D. F. (2019c). Budgeting and budgetary control in the agricultural sector: Critical elements in enhancing economic growth in Nigeria (pp. 433-446). Proceedings of the 33rd International Business Information Management Association Conference, IBIMA 2019: Education Excellence and Innovation Management through Vision 2020.

Oladipo, O. A., Iyoha, O. F., Fakile, A. S., Asaleye, A. J., \& Eluyela, D. F. (2019a). Do government taxes have implications on manufacturing sector output? Evidence from Nigeria. Journal of Management Information and Decision Sciences, 22(3), 181-190.

Oladipo, O. A., Iyoha, O. F., Fakile, A. S., Asaleye, A. J., \& Eluyela, D. F. (2019b). Tax revenue and agricultural performance: evidence from Nigeria. Problems and Perspectives in Management, 17(3), 342-349. https://doi.org/10.21511/ppm.17(3).2019.27

Olalere, O. E., \& Wan, A. B. O. (2016). Risk Management and the Financial Performance of commercial Banks in Nigeria: A Literature Review Revisited. IOSR Journal of Economics and Finance (IOSR-JEF), 7(2), 14-19.

Otekunrin, A. O., Nwanji, T. I., Agba, D. Z., Olowookere, J. K., Fakile, S. A., Ajayi, S. A., ... Oladiran, T. (2018). Outsourcing of accounting services and strategic cost management method: (A case study of Dangote flour PLC and Doyin Investment Nig. LTD). Proceedings of the 32nd International Business Information Management Association Conference, IBIMA 2018, 8452-8465. 
Otekunrin, A. O., Nwanji, T. I., Olowookere, J. K., Egbide, B., Fakile, S. A., Lawal, A. I., .. Eluyela, F. D. (2018). Financial Ratio Analysis and Market Price of Share of Selected Quoted Agriculture and Agro-allied Firms in Nigeria AfterAdoption of International Financial Reporting Standard. The Journal of Social Sciences Research, 12(4), 736-744. https://doi.org/10.32861/jssr.412.736.744

Ozordi, E., Adetula, D. T., Eluyela, D. F., Aina, A., \& Ogabi, M. (2019). Corporate dynamism and cash holding decision in listed manufacturing firms in Nigeria. Problems and Perspectives in Management, 17(4), 1-12. https://doi.org/10.21511/ppm.17(4).2019.01

Ozordi, E., Eluyela, D. F., Uwuigbe, U., Uwuigbe, O. R., \& Nwaze, C. E. (2020). Gender diversity and sustainability responsiveness: evidence from Nigerian fixed money deposit banks. Problems and Perspectives in Management, 18(1), 119-129. https://doi.org/10.21511/ppm.18(1).2020.11

Pagach, D., \& Warr, R. (2011). The characteristics of firms that hire chief risk officers. Journal of Risk and Insurance, 78(1), 185-211.

Popoola, O., Asalaye, A. J., \& Eluyela, D. F. (2018). Domestic revenue mobilization and Agricultural productivity: evidence from Nigeria. Journal of Advanced Research in Law and Economics, 4(34), 1439-1450. https://doi.org/10.14505/jarle.v9.4(34).31

Quon, T. K., Zeghal, D., \& Maingot, M. (2012). Enterprise risk management and firm performance. Procedia Social and Behavioural Sciences, 62, 263-267. https://doi.org/10.1016/j.sbspro.2012.09.042.

Saeidi, P., Sofian, S., \& AbdulRasid, S. Z. B. (2014). International Journal of Information Processing and Management, 5(2), 70.

Saidu, S. A., \& Gidado, S. (2018). Managerial Ownership and Financial Performance of Listed Manufacturing Firms in Nigeria. International Journal of Academic Research in Business and Social Sciences, 8(9), 1227-1243. https://doi.org/10.6007/IJARBSS/v8-i9/4693

Smith, C., \& Stulz, R. (1985). The determinants of firms' hedging policies. Journal of Financial and Quantitative Analysis, 20(4), 391-405. https://doi.org/10.2307/2330757

Umukoro, O. E., Eluyela, D. F., Ozordi, E., Inua, O. I., \& Balogun, S. B. (2020). Nollywood Accounting and Financial Performance: evidence from Nigerian Cinemas. International Journal of Financial Research, 11(2), 271-280. https://doi.org/10.5430/ijfr.v11n2p271

\section{Copyrights}

Copyright for this article is retained by the author(s), with first publication rights granted to the journal.

This is an open-access article distributed under the terms and conditions of the Creative Commons Attribution license (http://creativecommons.org/licenses/by/4.0/). 